\title{
LA REFORMA POLÍTICA EN DEBATE. ANÁLISIS DE LAS ÚLTIMAS REFORMAS POLİTICO-ELECTORALES (DISCUTIDAS Y/O CELEBRADAS) EN LA ARGENTINA
}

\author{
Adriana Gallo (*) \\ IEALC/CONICET
}

\section{RESUMEN}

En esta investigación analizaremos las dos últimas reformas político-electorales discutidas y/o celebradas en la Argentina: una de ellas, promovida por el gobierno kirchnerista, sancionada en 2009, y la otra, impulsada por el gobierno macrista, debatida a lo largo de 2016, aún en tratamiento legislativo. En este trabajo, nos proponemos realizar una lectura crítica de ambos proyectos de Reforma Política, exponiendo primero el diagnóstico que precedió a cada una; pasando revista por los argumentos que han respaldado sendos propuestas. Posteriormente, analizaremos con detenimiento el contenido de ambas reformas, apuntando los efectos concretos de las cláusulas (reales con la primera y posibles con la segunda) esbozadas teóricamente o incorporadas con cada una. Así, a través de la evaluación de las tres elecciones transcurridas desde la sanción de la primera ley, consideraremos que no se lograron los objetivos previstos con ella. Pero, a su vez, tampoco hay evidencia — dada la experiencia internacional de los últimos años- de que las propuestas incluidas en el nuevo proyecto conlleven a tal finalidad.

\section{PALABRAS CLAVE:}

reforma kirchnerista, proyecto de reforma macrista, democratización, representatividad.

(•)E-mail: doctoraag75@hotmail.com

\section{ABSTRACT}

This research will analyze the last two political-electoral reforms carried out and/or under discussion in Argentina: the first, promoted by the Kirchnerist government, sanctioned in 2009, and the second, promoted by the Macrist government, debated throughout 2016 and still under legislative treatment. In this paper, we propose a critical reading of both Political Reform projects, first setting forth the assessment that preceded each one, then reviewing the arguments that have supported each proposal. Subsequently, we will analyze in detail the content of both reforms, pointing out the concrete effects of the clauses (real in the first case and possible in the second), theoretically outlined or incorporated with each one. Thus, through the evaluation of the three elections celebrated since the enactment of the first law, we will consider that the objectives set forth with its enactment were not achieved. But, at the same time, there is no evidence - based on recent international experience - that the proposals included in the new project will lead to this purpose.

\section{KEY WORDS :}

kirchnerist reform, macrist reformist proposal, democratization, representativeness.

RECEPCIÓN: 29/12/16

ACEPTACIÓN FINAL: 09/06/17 